\title{
Change in abundance of three phytophagous mite species (Acari: Eriophyidae, Tetranychidae) on quackgrass in the presence of choke disease
}

\author{
Brian G. Rector $^{1} \cdot$ Marcin Czarnoleski $^{2} \cdot$ Anna Skoracka $^{3}$ (D) \\ Marlena Lembicz 4
}

Received: 6 December 2015/ Accepted: 29 June 2016/Published online: 7 July 2016

(C) The Author(s) 2016. This article is published with open access at Springerlink.com

\begin{abstract}
Phytophagous mites and endophytic fungi may interact when sharing a host plant, potentially influencing one another's growth or population dynamics; however, interactions between them are poorly known and remain largely unexplored. In this study, quantitative associations between three species of phytophagous mites and the endophytic fungus Epichlö̈ bromicola Leuchtm. \& Schardl (Clavicipitaceae, Ascomycotina) on quackgrass, Elymus repens (L.) Gould are reported. The mites' abundance was assessed on field-collected grass shoots that were either exhibiting choke disease symptoms or without the fungus. Overall, the abundance of Tetranychus urticae and Aculodes mckenziei was significantly lower on quackgrass plants infected by E. bromicola compared to plants without the fungus. Conversely, populations of Abacarus hystrix were significantly larger on plants colonised by the fungus than on uninfected plants. Thus, the presence of this endophytic fungus may have divergent effects on different phytophagous mite species although the basis of these effects is not yet known.
\end{abstract}

Keywords Endophyte $\cdot$ Epichloë · Herbivory · Interspecific interactions · Poaceae · Symbiosis

Anna Skoracka

skoracka@amu.edu.pl

1 USDA-ARS, Great Basin Rangelands Research Unit, Reno, NV, USA

2 Institute of Environmental Sciences, Jagiellonian University, Gronostajowa 7, 30-387 Kraków, Poland

3 Department of Animal Taxonomy and Ecology \& Population Ecology Lab, Faculty of Biology, Adam Mickiewicz University, Umultowska 89, 61-614 Poznań, Poland

4 Department of Plant Taxonomy, Faculty of Biology, Adam Mickiewicz University, Umultowska 89, 61-614 Poznań, Poland 


\section{Introduction}

Spider mites (Tetranychidae) and eriophyoid mites (Eriophyoidea) are considered the most economically important taxa of all plant-feeding mites (Hoy 2011). Tetranychids typically have wide host ranges (Bolland et al. 1998), whereas the majority of eriophyoids are highly host specific (Skoracka et al. 2010). Tetranychidae are considered major plant pests worldwide, attacking food crops, trees, and ornamentals, causing serious yield losses. The most notorious pest species is the two-spotted spider mite, Tetranychus urticae Koch., which has a worldwide distribution and a wide host range (Bolland et al. 1998; Migeon and Dorkeld 2006-2011; Hoy 2011). Many of eriophyoids are also significant crop pests, some of which represent quarantine threats to numerous countries due to their direct feeding damage as well as transmission of plant diseases by some species (e.g. Duso et al. 2010; Navia et al. 2010).

Endophytic fungi are virtually ubiquitous symbionts living within plant tissues (Saikkonen et al. 2004; Cheplick and Faeth 2009; Rodriguez et al. 2009) that may protect their host plants either directly, e.g. through production of alkaloids that make them toxic or less palatable to herbivores (e.g. Bacon 1995; Elliot et al. 2000; Czarnoleski et al. 2012; García Parisi et al. 2014), or indirectly, e.g. by enhancing detection of mite (Schausberger et al. 2012) and even mammalian herbivores (Huitu et al. 2008) by predators. Alkaloids associated with the presence of endophytic fungi in grasses may reduce damage by herbivorous insects (Potter et al. 2008), via reduced feeding, oviposition (Rowan et al. 1990) or overall insect performance (Breen 1994; Clay and Schardl 2002). Not all endophytic fungi are known to benefit their hosts. For example, many epichloae (i.e. Epichloë and Neotyphodium species; Clavicipitaceae) are endophytes that produce no symptoms and are transmitted vertically through host lineages (i.e. via host seeds) without reproducing sexually themselves (Brem and Leuchtmann 2003; Schardl et al. 2013). However, some Epichloë spp., cause "choke disease", whereby they produce fruiting bodies (stromata) containing sexually reproductive spores and prevent flower and seed development in their hosts (Fig. 1). This disease is a significant threat to some economically important grasses (Western and Cavett 1959; Siegel et al. 1987; Brem and Leuchtmann 2003).

Although we know much about interactions of plant-symbiotic fungi with insects (e.g. Rowan et al. 1990; Breen 1994; Elliot et al. 2000; Clay and Schardl 2002; Potter et al. 2008; García Parisi et al. 2014), effects of these symbionts on mite herbivores have largely focused on interactions between root-associated microorganisms and the cosmopolitan pest, T. urticae (reviewed by Hoffmann and Schausberger 2012). For example, Zhang et al. (2012) demonstrated that the endophyte Neotyphodium gansuense Li \& Nan, which is associated with drunken horse grass, Achnatherum inebrians (Hance) Keng, reduced both feeding and survival of the spider mite Tetranychus urticae Koch.

The endophyte Epichlö̈ bromicola Leuchtm. \& Schardl has been recorded from numerous grass species and is known to produce choke disease in several of them (Brem and Leuchtmann 2003; Song and Nan 2015). The purpose of this study was to report quantitative and descriptive associations between choke-producing Ep. bromicola and the phytophagous mites Abacarus hystrix (Nal.), Aculodes mckenziei (Keif.) (both Eriophyidae) and T. urticae (Tetranychidae) on their shared host quackgrass, Elymus repens (L.) Gould. 
Fig. 1 Fertilized stromata of Epichloë bromicola on infected stems of quackgrass (Elymus repens). phot. M. Lembicz

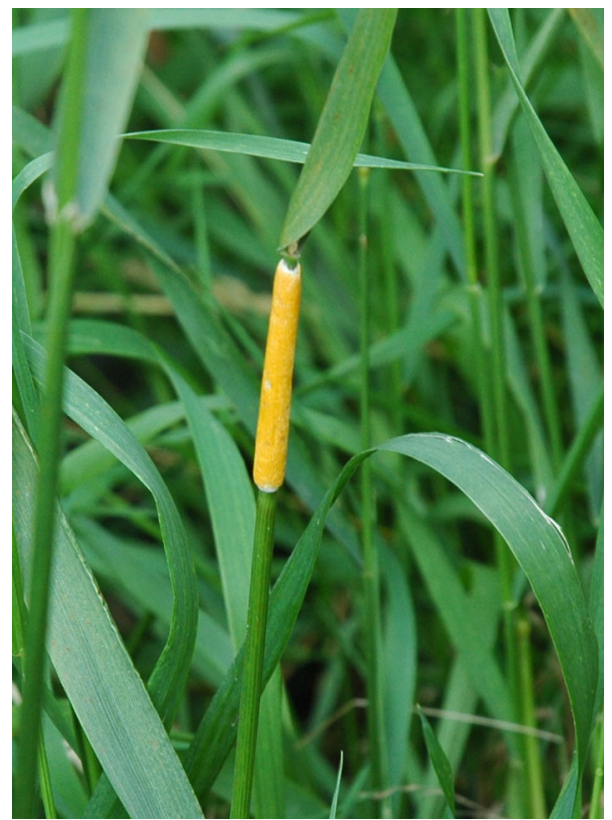

\section{Materials and methods}

The study plant, quackgrass (El. repens), is native to Europe and Asia. In Poland it is a common weed of field crops (Zając and Zając 2001). In May 2008, signs of the fungus Ep. bromicola were observed on the shoots of El. repens at two localities in Poland (Lembicz et al. 2010). In 2011, shoots of El. repens, with and without visible stromata of Ep. bromicola were collected from distinct clusters of El. repens shoots along four transects at three sites in Poland (Table 1). Each transect was $15 \mathrm{~m}$ long and $1 \mathrm{~m}$ wide. One shoot with and one shoot without stromata were collected from within each $1 \times 1 \mathrm{~m}$ square along the length of each transect. If there was no El. repens in a given square, no shoots were collected in that square. Plant shoots were placed separately in plastic bags inside a cooler. Each collected shoot, whether with or without visible signs of choke disease, was checked for the presence of the endophytic form of the fungus, which is evident from hyphae in intercellular spaces that stain dark blue with aniline blue dye. Specimens were analysed using a light microscope. The fungus on collected shoots was identified as Ep. bromicola, based on matching of nucleotide sequences of $t u b B$ introns (GenBank Accession No. DQ267692). Molecular identification followed the procedures of Brem and Leuchtmann (2003) and Lembicz et al. (2010). Each shoot designated as being without stromata was further tested for the presence of the asexual, asymptomatic stage of the fungus with aniline blue staining of leaf sheath epidermis and observations under a light microscope.

For each collected shoot, the length and the number of leaves were recorded and these measures were used to estimate the relative sizes of the plants (see below). The shoots were also examined under a stereo-microscope (Olympus SZX16) to detect mites. Mites were counted and were subsequently mounted on slides in Heinze medium (Heinze 1952; de Lillo et al. 2010). Mites were then identified to species (Manson 1967; Baker and Tuttle 1994; Skoracka 2004, 2009) using an Olympus BX41 phase-contrast light microscope. 
Table 1 Characteristics of the sampled sites. Please note that the raw data on the abundance of mites are not adjusted by differences in plant size

\begin{tabular}{|c|c|c|c|c|c|c|c|c|c|}
\hline \multirow[t]{2}{*}{$\begin{array}{l}\text { Site } \\
\text { name }\end{array}$} & \multirow[t]{2}{*}{$\begin{array}{l}\text { GPS } \\
\text { coordinates }\end{array}$} & \multirow[t]{2}{*}{$\begin{array}{l}\text { Epichlö̈ } \\
\text { presence }\end{array}$} & \multirow[t]{2}{*}{$\begin{array}{l}\text { No. of shoots } \\
\text { sampled }\end{array}$} & \multicolumn{3}{|c|}{ No. of shoots with } & \multicolumn{3}{|c|}{$\begin{array}{l}\text { Mean no. of mites per } \\
\text { shoot }\end{array}$} \\
\hline & & & & $\mathrm{ABH}$ & $\mathrm{ACM}$ & TEU & $\mathrm{ABH}$ & $\mathrm{ACM}$ & TEU \\
\hline \multirow[t]{2}{*}{$\begin{array}{l}\text { Dulsk } 1 \\
\text { (D1) }\end{array}$} & $\begin{array}{c}\mathrm{N} 52^{\circ} 45^{\prime} \\
23.42^{\prime \prime}\end{array}$ & No & 10 & 9 & 1 & 1 & 13.7 & 0.8 & 1.3 \\
\hline & $\begin{array}{c}\mathrm{E} 18^{\circ} 21^{\prime} \\
22.03^{\prime \prime}\end{array}$ & Yes & 11 & 11 & 1 & 4 & 42.2 & 0.1 & 1.1 \\
\hline \multirow[t]{2}{*}{$\begin{array}{l}\text { Dulsk } 2 \\
\text { (D2) }\end{array}$} & $\begin{array}{l}\mathrm{N} 52^{\circ} \\
\quad 45^{\prime} 11.32^{\prime \prime}\end{array}$ & No & 11 & 9 & 4 & 11 & 17.6 & 22.8 & 184.9 \\
\hline & $\begin{array}{l}\mathrm{E} 18^{\circ} \\
19^{\prime} 35.27^{\prime \prime}\end{array}$ & Yes & 12 & 5 & 0 & 6 & 2.5 & 0 & 32.6 \\
\hline \multirow[t]{2}{*}{$\begin{array}{l}\text { Jacewo } \\
\text { (J) }\end{array}$} & $\begin{array}{c}\mathrm{N} 52^{\circ} 48^{\prime} \\
02.88^{\prime \prime}\end{array}$ & No & 13 & 12 & 3 & 5 & 9.6 & 2.6 & 2.1 \\
\hline & $\begin{array}{c}\text { E } 18^{\circ} 17^{\prime} \\
50.78^{\prime \prime}\end{array}$ & Yes & 12 & 8 & 0 & 7 & 5.7 & 0 & 4.5 \\
\hline \multirow[t]{2}{*}{$\begin{array}{l}\text { Pakość } \\
(\mathrm{P})\end{array}$} & $\begin{array}{c}\mathrm{N} 52^{\circ} 48^{\prime} \\
06.23^{\prime \prime}\end{array}$ & No & 11 & 7 & 0 & 2 & 36.5 & 0 & 1.3 \\
\hline & $\begin{array}{c}\text { E } 18^{\circ} 05^{\prime} \\
07.76^{\prime \prime}\end{array}$ & Yes & 17 & 13 & 0 & 6 & 32.0 & 0 & 9.8 \\
\hline
\end{tabular}

ABH Abacarus hystrix, ACM Aculodes mackenziei, TEU Tetranychus urticae

\section{Data analysis}

Before statistical analysis the data on shoot length and number of leaves per shoot were $\log 10$-transformed and a Principal Components Analysis was performed on these values. We used the scores of the first principal component as our integrated measure of plant size.

To examine links between endophyte presence and abundance of mites on quackgrass, a Generalized Linear Model (GLM) was employed for the number of mites on plant shoots, assuming Poisson distribution and a log-link function. A separate analysis was performed for each mite species and each model included infection status and study location as grouping variables. Larger plants were expected to harbor larger numbers of mites. To eliminate this bias caused by a simple scaling effect, our models considered the index of plant size as a numerical covariate. Thus, comparisons between our study groups were made for plants adjusted to the mean plant size. The analyses were performed using Statistica 10 (StatSoft, Poland).

\section{Results}

Three species of mites were collected from the El. repens shoots: the polyphagous spider mite $T$. urticae (Tetranychidae) and two plant mites that are commonly found on grasses, $A b$. hystrix and Ac. mackenziei (both Eriophyidae). The most numerous species was $A b$. hystrix, followed by T. urticae, whereas Ac. mackenziei was found in very small numbers (Table 1). 
The PCA of leaf number and shoot length showed that both parameters were highly positively correlated and they formed the first principal component (i.e. our index of plant size in subsequent analyses), explaining $92 \%$ of the variation in the data (loadings of both parameters were equal to 0.96).

As predicted, results of the GLM (Table 2) indicated that larger plants harboured more mites. After accounting for this scaling effect, we found that T. urticae and Ac. mckenziei were most abundant on endophyte-free plants, in contrast to Ab. hystrix, which was found in the highest numbers on endophyte-infected plants (Fig. 2a). The abundance of mites also differed between the study sites; T. urticae and Ac. mckenziei were most abundant at the Dulsk 2 (D2) site; whereas Ab. hystrix reached the highest numbers in Pakość (P) and both Dulsk (D1 and D2) sites (Fig. 2b).

\section{Discussion}

Our comparative study revealed a complex pattern in the co-occurrence of phytophagous mites and an endophytic fungus on quackgrass. The mites T. urticae and Ac. mckenziei were most abundant on endophyte-free plants, which was consistent with our expectations that the presence of endophyte can result in lower pressure of phytohagous mites on grass. At the same time we found more mites of $A b$. hystrix on endophyte-infected plants, which was contrary to our hypothesis. This suggests that the presence of an endophyte, in this case the sexual form of E. bromicola may have contrasting effects on different species of phytophagous mites feeding on the diseased host plant. Such divergent effects have also been observed in phytophagous insects of different orders and differing host acceptance traits (i.e. generalist vs. specialist) in response to host infection by fungal endophytes (Gange et al. 2012). We also consider that the overall interaction between mites and the endophyte can be much more complex, as it involves direct interactions between the three species of mites. Such interactions could explain why the increased abundance of $T$. urticae and Ac. mckenziei on endophyte-free plants coincided with the reduced abundance of $A b$. hystrix. In the study presented here the two mite species that were less abundant on choked El. repens, viz. T. urticae and Ac. mackenziei, were also less abundant in general than $A b$. hystrix, regardless of the presence of Ep. bromicola (Fig. 2a). This would be

Table 2 Results of generalized linear models (likelihood type 3 test) examining the effects of endophytic infection and study site (grouping predictors), and plant size (numerical predictorcovariate) on the number of mites infesting plants. Data on each mite species were analyzed with a separate model. Please note that the model adjusted comparisons between groups for a mean plant size

\begin{tabular}{lccrl}
\hline & df & Log-likelihood & Chi-square & \multicolumn{1}{l}{$p$} \\
\hline Tetranychus urticae & & & & \\
Study site & 3 & -4340.48 & 4667.772 & 0.000001 \\
Endophyte presence & 1 & -2117.72 & 222.255 & 0.000001 \\
Plant size index & 1 & -2136.41 & 259.638 & 0.000001 \\
Abacarus hystrix & & & & \\
Study site & 3 & -2239.76 & 833.3133 & 0.000001 \\
Endophyte presence & 1 & -1845.89 & 45.5701 & 0.000001 \\
Plant size index & 1 & -1909.06 & 171.9009 & 0.000001 \\
Aculodes mckenziei & & & & \\
Study site & 2 & -527.357 & 342.4036 & 0.000001 \\
Endophyte presence & 1 & -389.633 & 66.9559 & 0.000001 \\
Plant size index & 1 & -461.451 & 210.5917 & 0.000001 \\
\hline
\end{tabular}


Fig. 2 a Number of mites belonging to three species occupying the grass Elymus repens either with or without the endophytic fungus Epichlö bromicola. b Difference in the number of mites on plants at different study sites. Because the number of mites was positively related to the size of plants, the graphs show mean numbers of mites with confidence intervals, modeled for an average-size plant (see Table 2)
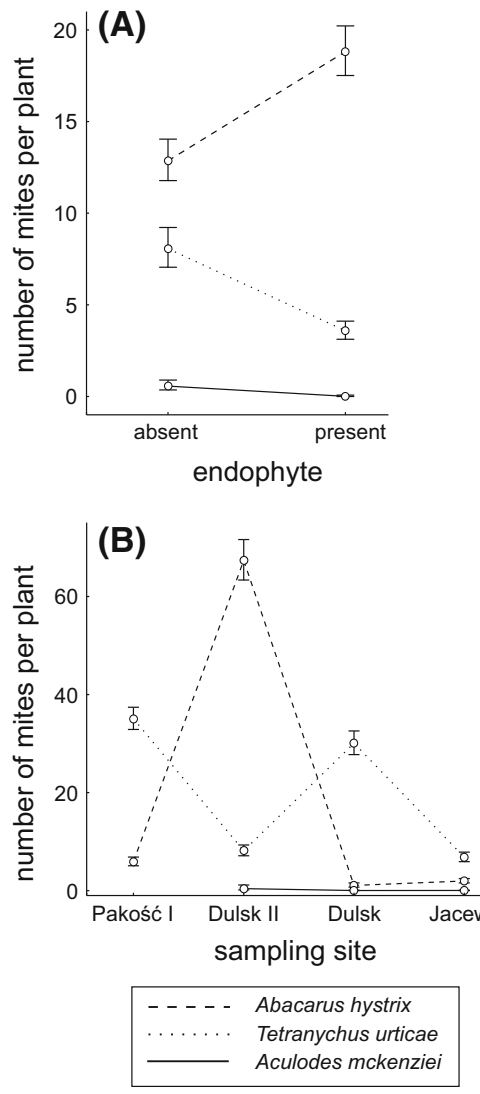

expected if the presence of Ep. bromicola in only a subset of El. repens plants provided a competitive advantage to local populations of $A b$. hystrix, compared to T. uriticae and $A c$. mackenziei, where all three species are utilizing El. repens. Manipulative experiments testing one mite species at a time will be necessary to properly quantify these interactions although such studies are complicated by the unpredictable nature of the development of the sexually reproductive forms of Epichloë spp. (characterized by the choke disease of their hosts), which may depend on environmental, geographical, or genotypic (either host or endophyte) factors (reviewed by Tadych et al. 2014). As such, although the results of the study presented here are preliminary, they provide information that should stimulate further investigation into the possible roles of endophytes in mite-plant interactions, which are largely unknown to date.

The results of this study suggest that herbivorous mite presence may be either positively or negatively correlated with the presence of choke in a grass host, depending on the species. This echoes studies of herbivorous mites sharing host plants with phytopathogenic fungi, in which either greater or lesser mite abundance has been observed in the presence of a fungus depending on the system. For example, mango bud tissue colonized by Fusarium mangiferae Britz, Wingfield \& Marasas, and wheat and quackgrass leaves colonized by Puccinia spp., supported significantly higher populations of eriophyoid mites compared to healthy plants (Gamliel-Atinsky et al. 2010). Similarly, densities and 
incidence of $T$. urticae were greater on apple and cherry leaves infected with powdery mildew than on healthy leaves collected from orchards (Reding et al. 2001). Conversely, populations of $T$. urticae grew less rapidly on plants that had been inoculated with the fungal pathogen Verticilium dabliae Kleb. than on disease-free control plants (Karban et al. 1987). Herbivorous mites may increase the incidence and severity of fungal infection on host plants either by vectoring pathogen spores on their bodies (Batra and Stavely 1994; Abdel-Sater and Eraky 2001; Gamliel-Atinsky et al. 2010) or by providing wound-sites for fungal penetration (Petty et al. 2002; Cardenas et al. 2003). Of the mite species observed in this study, only $A b$. hystrix appears to be a candidate for vectoring Ep. bromicola between El. repens plants, given the positive correlation between the presence of choke disease and $A b$. hystrix abundance. Further studies would be required to ascertain such a role for this mite species.

As part of this study, the control plants (i.e. those without choke symptoms) were tested to ensure that asymptomatic Ep. bromicola was not present. However, given that many Epichloë spp., including Ep. bromicola, occur as either asexual, asymptomatic or sexual, choke-producing forms (Brem and Leuchtmann 2003; Schardl et al. 2013), one question that arises from this study is whether the observed differences in mite abundance in the presence of choke symptoms would also occur in the presence of the asexual, asymptomatic form of Ep. bromicola. Indeed, in one such experiment, fall armyworm (Spodoptera frugiperda Smith) larvae that were fed red fescue (Festuca rubra L.) infected with asymptomatic Epichloë typhina (Pers.) Tul., did not survive to pupation, compared to $43 \%$ survival on red fescue without Ep. typhina (Clay et al. 1993), showing that the presence of choke-disease symptoms was not necessary to affect these herbivores.

Recent studies (Gange et al. 2007; Eschen et al. 2010) have revealed differing effects on insect herbivores from either single or multiple endophyte. It is not known if any additional endophyte species were present within the choked El. repens plants in this study, although given the breadth of endophyte species recorded from Elymus (Ringelberg et al. 2012) and other grass species (Baynes et al. 2012), it is possible that one or more asymptomatic endophyte species could have been present in combination with Ep. bromicola in the El. repens plants analyzed in this study, with unpredictable effects. Clearly, at this time the multitrophic effects of microbial plant symbionts represent a great opportunity for future study in the field of plant ecology.

Acknowledgments The work was supported by Grant NN 303472138 from the Polish Ministry of Science. The authors thank to professor Julian Chmiel (AMU Poland) for help in the field work and professor Adrian Leuchtmann (ETH Zurich) for help in endophyte species identification, to the editor of Experimental and Applied Acarology and two anonymous reviewers for their helpful remarks that improved the manuscript.

Author contributions ML and AS conceived and designed the study, ML collected and identified plant and fungus material, AS collected and identified animal material. MC statistically analyzed the data, BR wrote the manuscript with assistance from AS, ML, MC. The final manuscript was read and approved by all authors.

\section{Compliance with ethical standards}

Conflict of interest The authors declare that they have no conflict of interest.

Ethical approval This article does not contain any studies with human participants or animals performed by any of the authors. 
Informed consent Informed consent was obtained from all individual participants included in the study.

Open Access This article is distributed under the terms of the Creative Commons Attribution 4.0 International License (http://creativecommons.org/licenses/by/4.0/), which permits unrestricted use, distribution, and reproduction in any medium, provided you give appropriate credit to the original author(s) and the source, provide a link to the Creative Commons license, and indicate if changes were made.

\section{References}

Abdel-Sater MA, Eraky SA (2001) Bulbs micoflora and their relation with three stored product mites. Mycopathologia 153:33-39

Bacon CW (1995) Toxic endophyte-infected tall fescue and range grasses: historic perspectives. J Anim Sci 73:861-870

Baker EW, Tuttle DM (1994) A guide to the spider mites (Tetranychidae) of the United States. Indira Publishing House, West Bloomfield

Batra LR, Stavely JR (1994) Attraction of twospotted spider mite to bean rust uredinia. Plant Dis 78:282

Baynes MA, Newcombe G, Dixon L, Castlebury L, O’Donnell K (2012) A novel plant-fungal mutualism associated with fire. Fungal Biol 116:133-144

Bolland HR, Gutierrez J, Flechtmann CHW (1998) World catalogue of the spider mite family (Acari: Tetranychidae). Brill, Leiden

Breen JP (1994) Acremonium endophyte interactions with enhanced plant resistance to insects. Annu Rev Entomol 39:401-423

Brem D, Leuchtmann A (2003) Molecular evidence for host-adapted races of the fungal endophyte Epichlö̈ bromicola after presumed host shifts. Evolution 57:37-51

Cardenas RM, Gonzalez L, Parra Y, Rivero D, Cruz A (2003) Influence of rice grain discoloration (Oryza sativa Lin.) on variety J-104, harmfulness and genera of fungi present. Rev Prot Veg 18:124-128

Cheplick GP, Faeth SH (2009) Ecology and evolution of the grass-endophyte symbiosis. Oxford University Press, Oxford

Clay K, Schardl C (2002) Evolutionary origins and ecological consequences of endophyte symbiosis with grasses. Am Nat 160:S99-S127

Clay K, Marks S, Cheplick GP (1993) Effects of insect herbivory and fungal endophyte infection on competitive interactions among grasses. Ecology 74:1767-1777

Czarnoleski M, Pawlik K, Olejniczak P, Kozłowski J, Lembicz M (2012) An endophytic fungus reduces herbivory in its recently colonised grass host: a food-choice experiment on common voles, weeping alkaligrass and Epichloe typhina. Plant Ecol 213:1049-1053

de Lillo E, Craemer C, Amrine JW, Nuzzaci G (2010) Recommended procedures and techniques for morphological studies of Eriophyoidea (Acari: Prostigmata). Exp Appl Acarol 51:283-307. doi:10. 1007/s10493-009-9311-x

Duso C, Castagnoli M, Simoni S, Angeli G (2010) The impact of eriophyoids on crops: recent issues on Aculus schlechtendali, Calepitrimerus vitis and Aculops lycopersici. Exp Appl Acarol 51:151-168

Elliot SL, Sabelis MW, Janssen A, van der Geest LPS, Beerling EAM, Fransen J (2000) Can plants use entomopathogens as bodyguards? Ecol Lett 3:228-235

Eschen R, Hunt S, Mykura C, Gange AC, Sutton BC (2010) The foliar endophytic fungal community composition in Cirsium arvense is affected by mycorrhizal colonization and soil nutrient content. Fungal Biol 114:991-998

Gamliel-Atinsky E, Freeman S, Maymon M, Belausov E, Ochoa R, Skoracka A, Peńa J, Palevsky E (2010) The role of eriophyoids in fungal pathogen epidemiology, mere association or true interaction? Exp Appl Acarol 51:191-204

Gange AC, Dey S, Currie AF, Sutton BC (2007) Site- and species-specific differences in endophyte occurrence in two herbaceous plants. J Ecol 95:614-622

Gange AC, Eschen R, Wearn JA, Thawer A, Sutton BC (2012) Differential effects of foliar endophytic fungi on insect herbivores attacking a herbaceous plant. Oecologia 168:1023-1031

García Parisi PA, Grimoldi AA, Omacini M (2014) Endophytic fungi of grasses protect other plants from aphid herbivory. Fungal Ecol 9:61-64

Heinze K (1952) Polyvinylalkohol-Lactophenol-Gemisch als Einbettungsmittel fur Blattlause. Naturwissenschaften 39:285-286. doi:10.1007/BF00591256

Hoffmann D, Schausberger P (2012) Plant-mediated aboveground-belowground interactions: the spider mite perspective. Acarologia 52:17-27

Hoy M (2011) Agricultural acarology: introduction to integrated mite management. CRC Press, Boca Raton 
Huitu O, Helander M, Lehtonen P, Saikkonen K (2008) Consumption of grass endophytes alters the ultraviolet spectrum of vole urine. Oecologia 156:333-340

Karban R, Adamchak R, Schnathorst WC (1987) Induced resistance and interspecific competition between spider mites and a vascular wilt fungus. Science 235:678-680

Lembicz M, Górzyńska K, Leuchtmann A (2010) Choke disease, caused by Epichloë bromicola, in the grass Agropyron repens in Poland. Plant Dis 94:1372

Manson DCM (1967) The spider mite family Tetranychidae in New Zealand. II. The genus Tetranychus Acarologia 9:581-597

Migeon A, Dorkeld F, (2006-2011) Spider mites web: a comprehensive database for the Tetranychidae. http://www.montpellier.inra.fr/CBGP/spmweb. Accessed 2 Oct 2015

Navia D, Ochoa R, Welbourn C, Ferragut F (2010) Adventive eriophyoid mites: a global review of their impact, pathways, prevention and challenges. Exp Appl Acarol 51:225-255

Petty G, Stirling G, Bartholomew D (2002) Pests of pineapple. In: Peña JE, Sharp J, Wysoki M (eds) Tropical fruit pests and pollinators: their economic importance, natural enemies and control. $\mathrm{CAB}$ International, Wallingford, pp 157-196

Potter DA, Stokes JT, Redmond CT, Schardl CL (2008) Contribution of ergot alkaloids to suppression of a grass-feeding caterpillar assessed with gene knockout endophytes in perennial ryegrass. Entomol Exp Appl 126:138-147

Reding ME, Alston DG, Thomson SV, Stark AV (2001) Association of powdery mildew and spider mite populations in apple and cherry orchards. Agr Ecosyst Environ 84:177-186

Ringelberg D, Foley K, Reynolds CM (2012) Bacterial endophyte communities of two wheatgrass varieties following propagation in different growing media. Can J Microbiol 58:67-80

Rodriguez RJ, White JF Jr, Arnold AE, Redman RS (2009) Fungal endophytes: diversity and functional roles. New Phytol 182:314-330

Rowan DD, Dymock JJ, Brimble MA (1990) Effect of fungal metabolite peramine and analogs on feeding and development of Argentine stem weevil (Listronotus bonariensis). J Chem Ecol 16:1683-1695

Saikkonen K, Wäli P, Helander M, Faeth SH (2004) Evolution of endophyte-plant symbioses. Trends Plant Sci 9:275-280

Schardl CL, Florea S, Pan J, Nagabhyru P, Bec S, Calie PJ (2013) The epichloae: alkaloid diversity and roles in symbiosis with grasses. Curr Opin Plant Biol 16:480-488

Schausberger P, Peneder S, Juerschik S, Hoffman D (2012) Mycorrhiza changes plant volatiles to attract spider mite enemies. Funct Ecol 26:441-449

Siegel MR, Latch GC, Johnson MC (1987) Fungal endophytes of grasses. Annu Rev Phytopathol 25:293-315

Skoracka A (2004) Eriophyoid mites from grasses in Poland (Acari: Eriophyoidea). Genus 13:1-205

Skoracka A (2009) Description of Abacarus lolii n. sp. (Acari: Prostigmata: Eriophyoidea), a cryptic species within a grass-feeding Abacarus complex. Int J Acarol 35:405-417

Skoracka A, Smith L, Oldfield G, Cristofaro M, Amrine JW (2010) Host-plant specificity and specialization in eriophyoid mites and their importance for the use of eriophyoid mites as biocontrol agents of weeds. Exp Appl Acarol 51:93-113

Song H, Nan Z (2015) Origin, divergence, and phylogeny of asexual Epichloë Endophyte in Elymus species from western China. PLoS One 10(5):e0127096

Tadych M, Bergen MS, White JF (2014) Epichloe spp. associated with grasses: new insights on life cycles, dissemination and evolution. Mycologia 106:181-201

Western JH, Cavett JJ (1959) The choke disease of cocksfoot (Dactylis glomerata) caused by Epichloë typhina. (Fr.) Tul. T Brit Mycol Soc 42:298-307

Zając A, Zając M (2001) Distribution atlas of vascular plants in Poland. Laboratory of computer chorology, Institute of botany. Jagiellonian University, Kraków

Zhang XX, Li CJ, Nan ZB, Matthew C (2012) Neotyphodium endophyte increases Achnatherum inebrians (drunken horse grass) resistance to herbivores and seed predators. Weed Res 52:70-78 